\title{
The Rosenberg Self-Esteem Scale: Translation and Validation in University Students
}

\author{
José Martín-Albo, Juan L. Núñez, José G. Navarro, and Fernando Grijalvo \\ Universidad de Las Palmas de Gran Canaria (Spain)
}

\begin{abstract}
The aim of this study was to translate into Spanish and to validate the Rosenberg Self-Esteem Scale (RSES), completed by 420 university students. Confirmatory factor analysis revealed that the model that best fit the data, both in the total sample and in the male and female subsamples, was the one-factor structure with method effects associated with positively worded items. The results indicated high, positive correlations between self-esteem and the five dimensions of selfconcept. The scale showed satisfactory levels of internal consistency and temporal stability over a four-week period. Lastly, gender differences were obtained. These findings support the use of the RSES for the assessment of self-esteem in higher education.

Keywords: self-esteem, psychometric properties, college students, Rosenberg
\end{abstract}

El propósito de esta investigación ha sido traducir al español y analizar las propiedades psicométricas de la escala de autoestima de Rosenberg (RSES) en una muestra de estudiantes universitarios. El análisis factorial confirmatorio confirmó que el modelo que mejor se ajusta a los datos tanto en la muestra total como en las submuestras de hombres y mujeres tiene una estructura unifactorial con efectos de método en los ítems formulados en positivo. Los resultados indican correlaciones positivas y fuertes entre la autoestima y cinco dimensiones del autoconcepto. Además, la escala ha mostrado niveles satisfactorios de consistencia interna y estabilidad temporal tras un periodo de cuatro semanas. Finalmente, se han obtenido diferencias de género significativas. Estos resultados apoyan el uso de la RSES para evaluar la autoestima en el contexto educativo universitario.

Palabras clave: autoestima, propiedades psicométricas, estudiantes universitarios, Rosenberg

Correspondence concerning this article should be addressed to José Martín-Albo, Departamento de Psicología y Sociología, Universidad de Las Palmas de Gran Canaria, C/ Santa Juana de Arco, 1 - 35004 Las Palmas (Spain). E-mail: jmartin@dps.ulpgc.es

Translation: Virginia Navascués Howard 
At the conceptual level, self-esteem has traditionally been considered an evaluative component of the self-concept (Purkey, 1970; Shavelson, Hubner, \& Stanton, 1976) by which subjects appraise their self-image from the feedback they receive as individuals and from information from social interaction during their diverse social roles (González-Pienda, Núñez, GonzálezPumariega, \& García, 1997). In this same line, Musitu, Román, and Gracia (1988) conceive self-esteem as a worth and evaluative quality of the cognitions and behaviors which is expressed in the degree of personal satisfaction. Recently, Garaigordobil, Durá, and Pérez (2005) established a hierarchical relation between self-concept and self-esteem in which the selfdescription serves the positive self-appraisal and this, in turn, plays a protective role in the person's system.

The study of self-esteem is essential in psychological research because it has been associated with, among other aspects, psychological well-being (Sánchez \& Barrón, 2003), self-handicapping strategies and defensive pessimism (Rodríguez, Cabanach, Valle, Núñez, \& González-Pienda, 2004), the influence of the environment and the family educational style (Alonso \& Román, 2005; Parra, Oliva, \& Sánchez, 2004), learning strategies (Núñez, et al., 1998), and academic achievement (Fiz \& Oyón, 1998; Mestre, García, Frías, \& Llorca, 1992). In this sense, it is crucial to have instruments to assess self-esteem adapted to our environment and with adequate psychometric properties.

One of the most extensively used instruments to assess self-esteem is the Rosenberg Self-Esteem Scale (RSES; Rosenberg, 1989). This author considers self-esteem a component of self-concept and defines it as an individual's set of thoughts and feelings about his or her own worth and importance, that is, a global positive or negative attitude toward oneself (Rosenberg, 1965). The RSES is a unidimensional instrument elaborated from a phenomenological conception of self-esteem that captures subjects' global perception of their own worth by means of a 10 -item scale, 5 positively worded items and 5 negatively worded items.

The RSES has been translated and adapted to various languages, such as Persian (Shapurian, Hojat, \& Nayerahmadi, 1987), French (Vallieres \& Vallerand, 1990), Chinese (Cheng \& Hamid, 1995), Italian (Prezza, Trombaccia, \& Armento, 1997), Estonian (Pullmann \& Allik, 2000), and Portuguese (Santos \& Maia, 2003).

The extensive diffusion of the instrument and the crosscultural studies in up to 53 different nations (Schmitt \& Allik, 2005) have revealed that the scale presents problems regarding its unidimensional structure. In this same line, Hensley and Roberts (1976), although they found a twofactor solution, they identified a unique response of a similar nature, so the scale probably only measures a single dimension. Moreover, as noted by Quilty, Oakman, and Risko (2006), the method effects should be included in the measurement model of the instrument in order to obtain a good fit. Thus, Wang, Siegal, Falck, and Carlson (2001) present the scale as unidimensional but including the method effects in the items that are positively worded, whereas most investigators include the method effects in the negatively worded items (Corwyn, 2000; Gana, Alaphilippe, \& Baillo, 2005; Marsh, 1996; Motl \& DiStefano, 2002). Other studies propose that the best fin is obtained when considering the method effects both in the positively and the negatively worded items (Quilty et al., 2006; Tomás \& Oliver, 1999). In contrast, other investigations propose that the solution of two correlated factors (one factor for the positively worded items and the other for the negatively worded items) presents the best goodness-of-fit indexes (Greenberger, Chen, Dmitrieva, \& Farruggia, 2003; Prezza et al., 1997).

In Spain, various studies have been carried out to analyze the psychometric properties of the RSES in clinical samples (Baños \& Guillén, 2000; Vázquez, Jiménez, \& VázquezMorejón, 2004), adolescent samples (Atienza, Moreno, \& Balaguer, 2000; Pastor, Navarro, Tomás, \& Oliver, 1997), and adults (Salgado \& Iglesias, 1995). However, these studies did not follow rigorous cross-cultural procedures to translate the scale, nor has the scale been validated in the university setting, which prevents the adequate use of the instrument to identify these students' self-esteem and to analyze the relations with other variables (i.e., motivation, self-concept, anxiety, and achievement).

Therefore, this work has the following goals: (a) to translate the original scale and adapt it to the university population, (b) to examine the factor structure of the RSES in a sample of university students by means of confirmatory factor analysis, (c) to evaluate construct validity, examining the relation among the five self-concept dimensions and self-esteem, (d) to evaluate scale reliability, specifically, internal consistency and temporal stability, and (e) to evaluate gender differences in self-esteem.

\section{Translation of the Scale}

Translation of the RSES into Spanish was carried out following the cross-cultural translation procedures (Núñez, Martín-Albo, \& Navarro, 2005). Firstly, the scale was translated from English into Spanish according to the parallel back-translation procedure (Brislin, 1986), in which a bilingual person translates the scale from its original language to the language under study. Another bilingual individual, who is unfamiliar with the original scale, re-translates this version back to the original language. To ensure a correct translation and avoid possible biases, the sequence just described was repeated twice, so that, in this study, four bilingual people carried out the parallel back-translation procedure, thus obtaining two pilot versions of the RSES in Spanish. Secondly, the items thus obtained were assessed by a committee made up of the individuals who participated in the translation process and two psychology professors who selected the items that had maintained the original meaning, and prepared the scale format and the instructions identically to the original version. Thus, the Spanish version 
of the RSES had 10 items rated on a 4-point Likert-type scale, ranging from 1 (totally disagree) to 4 (totally agree).

\section{Statistic Analyses}

Confirmatory factor analysis was performed with the AMOS 6.0 program to evaluate the factor structure of the scale. The SPSS 14.0 statistical package was used for the following analyses: Pearson's correlations among self-esteem and the five self-concept dimensions, Student's $t$-test for gender differences in self-esteem, Cronbach's alpha for internal consistency, and test-retest correlation to assess temporal stability.

\section{Study 1}

\section{Method}

\section{Participants}

In this study, a total of 420 students (296 women and 124 men) from the Universidad de Las Palmas de Gran Canaria were participants. Age range was between 17 and 58 years, mean age 21.29 years $(S D=4.96)$. The sample was obtained by simple random sampling without replacement with a confidence level of .95 and a maximum error of .05. The population comprised all the students registered in the university during the academic year $2004 / 2005$, which was 22.066 students. In a prior pilot study, the variance of the population in self-esteem was .27. The sample size resulting from the formula applied was 415 . Subjects were assigned to the sample using an alphabetic list of all the university students; that is, they were not assigned as a function of the faculties.

\section{Instruments}

The Rosenberg Self-Esteem Scale (RSES) is made up of 10 items that refer to self-respect and self-acceptance rated on a 4-point Likert-type scale, ranging from 1 (totally disagree) to 4 (totally agree). Items $1,3,4,7$, and 10 are positively worded, and items 2, 5, 6, 8, and 9 negatively.

We used the "Autoconcepto Forma 5" (AF5; in Spanish, "Self-concept Form 5 questionnaire"; García \& Musitu, 2001) to assess the five self-concept dimensions: (a) academic dimension, which refers to individuals' perception of the quality of their student role performance; (b) social dimension, which refers to subjects' perception of their performance in social relations; (c) emotional dimension, which involves people's perception of their emotional status; (d) family dimension, referring to the persons' perception of their involvement, participation, and integration in the family setting; and (e) physical dimension, which refers to the subjects' perception of their physical aspect and condition. Each dimension is made up of 6 items that are rated on a 99-point scale ranging from 1 (totally disagree with the item) to 99 (totally agree with the item).

\section{Procedure}

Two investigators administered the assessment instruments to the participants. In order to avoid as much as possible the social desirability effect, students were informed that their participation was voluntary and confidential. They were requested to respond as honestly as possible, and there was no time limit. The investigators provided the necessary help and made sure that the participants had completed the questionnaires correctly.

\section{Results}

\section{Descriptive Statistics}

In the descriptive analysis of the 10 items of the proposed model, and taking into account the skewness and curtosis indexes, the data set is similar to the normal distribution both in men and women (see Table 1), which permits the use of maximum likelihood factor tests.

Likewise, in Table 2 are displayed the results of the homogeneity indexes or item-total correlation of the items. The values range between a minimum of .44 and a maximum of $.77, p<.01$.

\section{Confirmatory Factor Analysis}

Confirmatory factor analysis was conducted to examine the underlying dimensional structure of the questionnaire, using mle (maximum likelihood estimate), as well as the item covariance matrix as input for data analysis. Eight factor models were studied, among which were included two correlated uniqueness models (CTCU) and three multitrait-multimethod models (CTCM). Specifically, the following models were contrasted: (a) Model 1, a 10-item unidimensional model; (b) Model 2, with 10 items and two independent factors (positively and negatively orientated items); (c) Model 3 with 10 items and two correlated factors (positively and negatively orientated items); (d and e) Models 4 and 5 (CTCU), which postulate the existence of one factor taking into account the residual covariances of the positive and negative items, respectively; (f) Model 6 (CTCM) with one global self-esteem factor and one method factor that includes the positive items; (g) Model 7 (CTCM) with one global self-esteem factor and one method factor that includes the negative items; and (h) Model 8 (CTCM) with one global self-esteem factor and two correlated method factors that include the positive items on the one hand, and the negatives items on the other. (See Figure 1). 
Table 1

Gender Differences as a function of the Means in the Variables of the Spanish Version of the Rosenberg Self-Esteem Scale

\begin{tabular}{|c|c|c|c|c|c|c|c|c|c|}
\hline \multirow{2}{*}{ Items (Spanish version) } & \multirow[b]{2}{*}{$M$} & \multicolumn{2}{|c|}{ Men } & \multicolumn{6}{|c|}{ Women } \\
\hline & & $S D$ & Skewness & Kurtosis & $M$ & $S D$ & Skewness & Kurtosis & $t$ \\
\hline En general, estoy satisfecho conmigo mismo ${ }^{*}$ & 3.24 & .60 & -.38 & .65 & 3.11 & .56 & -.20 & 1.13 & 2.01 \\
\hline A veces pienso que no soy bueno en nada ${ }^{*}$ & 2.04 & .98 & .60 & -.67 & 2.37 & .92 & .17 & -.79 & -3.26 \\
\hline Tengo la sensación de que poseo algunas buenas cualidades * & 3.35 & .59 & -.76 & 2.28 & 3.23 & .52 & .23 & -.14 & 2.11 \\
\hline \multicolumn{10}{|l|}{ Soy capaz de hacer las cosas tan bien como la mayoría } \\
\hline de las personas & 3.27 & .59 & -.12 & -.49 & 3.20 & .58 & -.14 & .23 & 1.13 \\
\hline \multicolumn{10}{|l|}{ Siento que no tengo demasiadas cosas de las que sentirme } \\
\hline orgulloso & 2.21 & 1.04 & .36 & -1.04 & 2.24 & .96 & .34 & -.82 & -.29 \\
\hline A veces me siento realmente inútil ${ }^{*}$ & 2.04 & 1.08 & .59 & -.98 & 2.32 & 1.04 & .23 & -1.11 & -2.47 \\
\hline \multicolumn{10}{|l|}{ Tengo la sensación de que soy una persona de valía al menos } \\
\hline igual que la mayoría de la gente & 3.35 & .67 & -1.03 & 1.78 & 3.24 & .61 & -.55 & 1.20 & 1.47 \\
\hline Ojalá me respetara más a mí mismo & 2.33 & 1.01 & .11 & -1.10 & 2.43 & 1.01 & .10 & -1.06 & -.94 \\
\hline En definitiva, tiendo a pensar que soy un fracasado & 1.90 & 1.14 & .91 & -.69 & 2.08 & 1.11 & .55 & -1.10 & -1.55 \\
\hline Tengo una actitud positiva hacia mí mismo * & 3.20 & .72 & -.72 & .57 & 3.01 & .72 & -.50 & .29 & 2.47 \\
\hline Total scale score ${ }^{*}$ & 32.53 & 3.92 & -.60 & .25 & 31.14 & 4.55 & -.38 & .07 & 2.59 \\
\hline
\end{tabular}

${ }^{*} p<.01$.

Table 2

Item-Total Correlation of the Rosenberg Self-Esteem Scale

\begin{tabular}{|c|c|c|c|c|c|c|c|c|c|c|}
\hline & Item 1 & Item 2 & Item 3 & Item 4 & Item 5 & Item 6 & Item7 & Item 8 & Item 9 & Item 10 \\
\hline Total score & $.52^{*}$ & $.71^{*}$ & $.44^{*}$ & $.54^{*}$ & $.61^{*}$ & $.73^{*}$ & $.48^{*}$ & $.63^{*}$ & $.70^{*}$ & $.70^{*}$ \\
\hline
\end{tabular}

${ }^{*} p<.01$.

Following the recommendations of $\mathrm{Hu}$ and Bentler (1999), as indexes to assess the fit of the models, we used the comparative fit index (CFI) and the incremental fit index (IFI) whose goodness-of-fit ranges are between 0 and 1 , considering the fit good if the value is equal to or higher than .95; the root mean square residual (SRMR), in which values of .06 or less indicate a good fit; and the root mean square error of approximation (RMSEA), which indicates that the model based on the sample employed represents the population if its value is equal to or lower than .05 , and considers the fit acceptable when it is lower than .08 (Jöreskog \& Sörbom, 1993). In addition, we used the ratio between chi-square and the degrees of freedom $\left(\chi^{2} / d f\right)$, which is a heuristic employed to reduce the sensitivity of $\chi^{2}$ to the sample size (Kline, 1998). In a model that is considered perfect, its value would be 1.0, and ratios lower than 2.0 are considered acceptable (Bollen \& Long, 1994).

When observing the data in Table 3, considering the total sample, the goodness-of-fit indexes show that Model 1 (unidimensional) had the worst fit, whereas Models 2 (two uncorrelated factors), 3 (two correlated factors), 5 (one factor and the error covariances of the negative items), 6 (one global factor and one method factor that includes the positive items), and 7 (one global factor and one method factor that includes the negative items) provided better fit to the data, and Model 4 (one factor and the error covariances of the positive items) presented the best goodness-of-fit indexes. Model 8 (one global factor and two correlated method factors) revealed an inadequate solution, that is, in the sample used, it had one or more parameters with estimation problems.

Considering the subsamples as a function of gender, Models 4 and 8 presented the best fit. In the men, both models had similar goodness-of-fit indexes. However, in the women, Model 4 presented worse indexes.

With regard to the item loadings, as can be observed in Table 4, in the one-factor Models 1 and 4, the loadings of the positive items were lower than .20 in absolute value, whereas the negative items reached loadings of over .50 . With regard to the two-factor Models 2 and 3, all the loadings were significant and higher than .39. In Model 5, the factor loadings of the negative items were lower than those of the positive items. In the two CTCM models (Models 6 and 7), the loadings of the items on the two method factors were similar to those found in the two-factor 


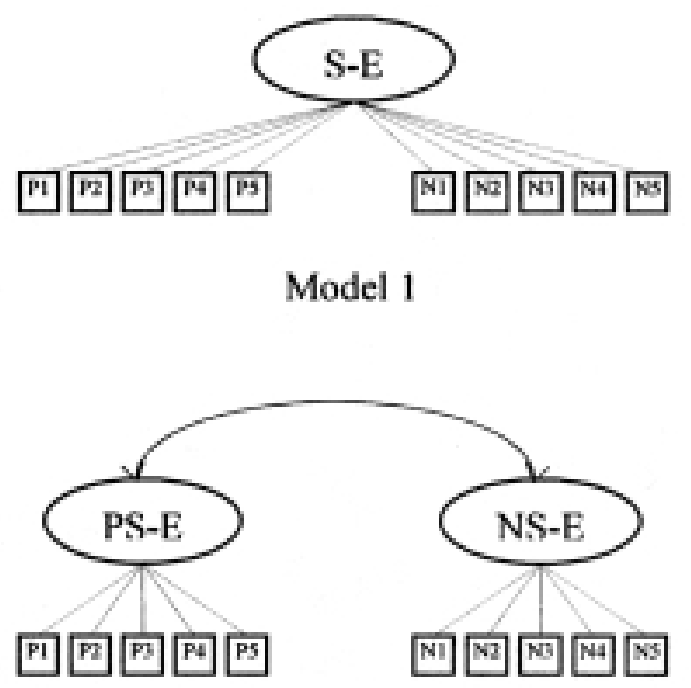

Model 3

\section{S-E}

田回回回四

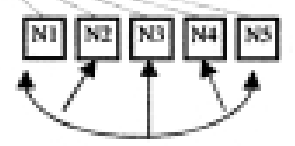

Model 5

S-E

回回回回

回四四四

$$
\text { NS-E }
$$

Model 7

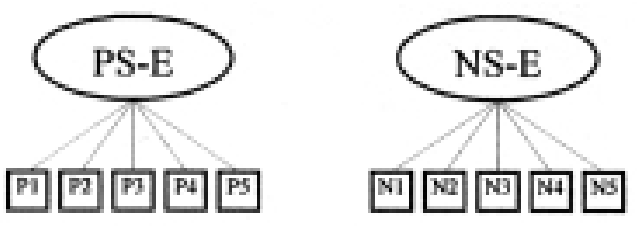

Model 2

S-E

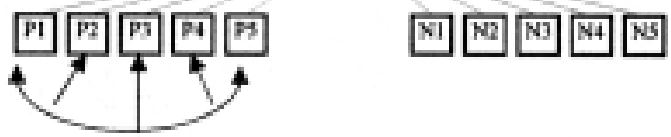

Model 4

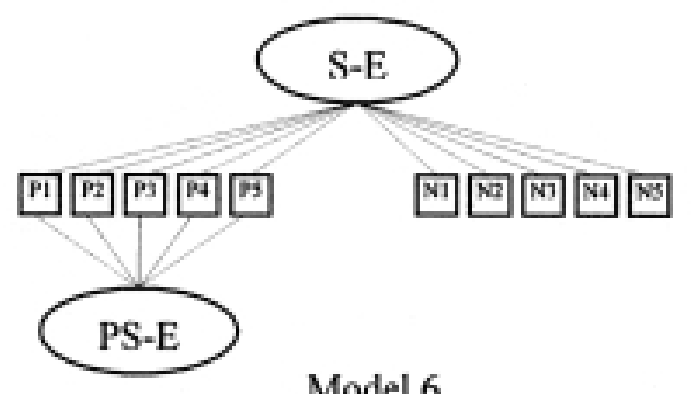

Model 6
S-E

用国同同

四因四四

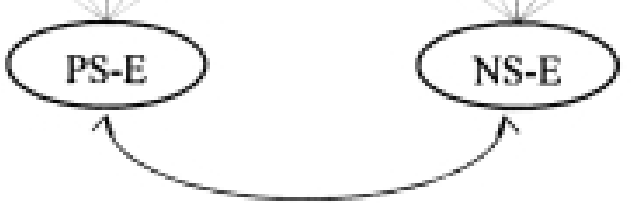

Model 8 
Table 3

Goodness-of-fit Indexes of the Factor Models Tested for the Rosenberg Self-Esteem Scale

\begin{tabular}{|c|c|c|c|c|c|c|c|}
\hline Total Sample & $\chi^{2}$ & $d f$ & $\chi^{2} / d f$ & SRMR & IFI & CFI & RMSEA \\
\hline Model 1 & 367.06 & 35 & 10.49 & .13 & .76 & .75 & .15 \\
\hline Model 2 & 131.17 & 35 & 3.75 & .08 & .93 & .93 & .08 \\
\hline Model 3 & 118.82 & 34 & 3.49 & .05 & .94 & .94 & .07 \\
\hline Model 4 & 37.66 & 25 & 1.51 & .05 & .99 & .99 & .03 \\
\hline Model 5 & 100.90 & 25 & 4.04 & .05 & .94 & .94 & .08 \\
\hline Model 6 & 117.33 & 30 & 3.91 & .05 & .94 & .94 & .08 \\
\hline Model 7 & 128.75 & 30 & 4.29 & .08 & .93 & .93 & .09 \\
\hline \multicolumn{8}{|l|}{ Model $8^{*}$} \\
\hline \multicolumn{8}{|c|}{ Male Subsample } \\
\hline Model 1 & 104.55 & 35 & 2.99 & .11 & .82 & .81 & .13 \\
\hline Model 2 & 48.83 & 35 & 1.39 & .08 & .96 & .96 & .06 \\
\hline Model 3 & 48.39 & 34 & 1.42 & .07 & .96 & .96 & .06 \\
\hline Model 4 & 22.91 & 25 & .92 & .03 & .99 & .99 & .01 \\
\hline Model 5 & 39.14 & 25 & 1.56 & .08 & .96 & .96 & .07 \\
\hline Model 6 & 46.10 & 30 & 1.54 & .07 & .96 & .96 & .07 \\
\hline Model 7 & 41.85 & 30 & 1.39 & .07 & .97 & .97 & .06 \\
\hline Model 8 & 17.74 & 24 & .74 & .03 & .99 & .99 & .01 \\
\hline \multicolumn{8}{|c|}{ Female Subsample } \\
\hline Model 1 & 311.85 & 35 & 8.91 & .14 & .73 & .72 & .16 \\
\hline Model 2 & 109.47 & 35 & 3.13 & .08 & .93 & .93 & .08 \\
\hline Model 3 & 99.94 & 34 & 2.94 & .05 & .93 & .93 & .08 \\
\hline Model 4 & 40.10 & 25 & 1.60 & .02 & .98 & .98 & .04 \\
\hline Model 5 & 80.40 & 25 & 3.22 & .05 & .95 & .94 & .09 \\
\hline Model 6 & 93.91 & 30 & 3.13 & .04 & .94 & .94 & .08 \\
\hline Model 7 & 99.27 & 30 & 3.31 & .05 & .93 & .93 & .09 \\
\hline Model 8 & 74.75 & 24 & 3.11 & .05 & .95 & .95 & .09 \\
\hline
\end{tabular}

Note. SRMR = standardized root mean square residual; IFI = incremental fit index; CFI = comparative fit index; RMSEA = root mean square error of approximation.

* Model with inappropriate solution.

Table 4

Standardized Loadings of the Items on the Diverse CTCU and CTCM (Global Factor / Method Factor) Factor Models in the Total Sample

\begin{tabular}{cccccccc}
\hline Items & Model 1 & Model 2 & Model 3 & Model 4 & Model 5 & Model 6 & Model 7 \\
\hline 1 & $.12^{*}$ & $.59^{*}$ & $.58^{*}$ & $.01^{*}$ & $.58^{*}$ & $-.10^{*} / .58^{*}$ & .58 \\
2 & $-.78^{*}$ & $.78^{*}$ & $.78^{*}$ & $.78^{*}$ & $-.18^{*}$ & $.78^{*}$ & $-.05 / .77^{*}$ \\
3 & .09 & $.39^{*}$ & $.39^{*}$ & -.06 & $.39^{*}$ & $-.07 / .38^{*}$ & .40 \\
4 & .12 & $.51^{*}$ & $.51^{*}$ & -.07 & $.52^{*}$ & $-.10 / .50^{*}$ & .52 \\
5 & $-.75^{*}$ & $.75^{*}$ & $.75^{*}$ & $.75^{*}$ & $-.15^{*}$ & $.76^{*}$ & $-.04 / .75^{*}$ \\
6 & $-.86^{*}$ & $.86^{*}$ & $.86^{*}$ & $.86^{*}$ & $-.18^{*}$ & $.86^{*}$ & $.01 / .86^{*}$ \\
7 & .15 & $.39^{*}$ & $.39^{*}$ & -.11 & $.40^{*}$ & $-.13^{*} / .37^{*}$ & .40 \\
8 & $-.54^{*}$ & $.54^{*}$ & $.54^{*}$ & $.54^{*}$ & $-.12^{*}$ & $.54^{*}$ & $-.04 / .53^{*}$ \\
9 & $-.83^{*}$ & $.83^{*}$ & $.83^{*}$ & $.83^{*}$ & $-.18^{*}$ & $.83^{*}$ & $-.05 / .83^{*}$ \\
10 & $.19^{*}$ & $.76^{*}$ & $.76^{*}$ & -.11 & $.75^{*}$ & $-.17^{*} / .74^{*}$ & .75 \\
\hline
\end{tabular}

${ }^{*} p<.05$. 
Models 2 and 3. According to these results, , in general, the one-factor models presented lower loadings, which could lead to a decrease in the internal consistency of the instrument in comparison to the two-factor models. Likewise, the values of the correlations of the uniqueness in Model 4 ranged between .07 and .52 and, in Model 5, between .41 and .70 . However, both in the total sample and in the subsamples by gender, Model 4 fulfilled the cut-off criteria in the goodness-of-fit indexes established by $\mathrm{Hu}$ and Bentler (1999).

\section{Correlations among Self-Esteem and the Self- Concept Dimensions}

The relation among the five self-concept dimensions (academic, social, emotional, family, and physical) and selfesteem were analyzed with Pearson's correlation coefficient, as we hypothesized a logical relation between these constructs. Specifically, the self-concept dimensions should be positively and significantly correlated to self-esteem. As can be seen in the correlation matrix in Table 5, the correlations between self-esteem and the five self-concept dimensions were positive and medium-high, with values between .28 and .50 . The correlation between self-esteem and emotional self-concept is noteworthy, at the significance level of $p<.01$.

\section{Gender Differences}

The analysis of gender differences in the mean scores of the 10 items of the scale was performed with Student's $t$-test, at the significance level of $p<.01$, and using Levene's test to estimate variance equality. The results show that men's and women's means were very similar, although we found five significant differences; specifically, the women scored higher than the men in items 2,6 , and 10 , whereas the men scored higher in items 1 and 3. Likewise, when taking the total self-esteem score into account, the men obtained a higher and more significant mean than the women (see Table 1), with an effect size of .16 , measured with Cohen's $d(d=.33)$.
Study 2

Method

\section{Participants}

To assess the temporal stability of the scale, a second sample of 65 university students was employed. This sample was made up of 43 women and 22 men, mean age of 21.81 years $(S D=5.38)$, who completed again the scale after a 4-week interval.

\section{Procedure and Instruments}

The RSES was completed using the same procedure as in the first study, but in this case, the participants were informed that they would have to respond to the questionnaire on two occasions, after a 4 -week interval. To prevent possible social desirability tendencies, the participants were instructed to use their ID-card number to identify their questionnaires.

\section{Results}

The internal consistency of the scale was assessed with Cronbach's alpha. The values obtained in the first and the second administration were .85 and .88 , respectively. The value of the test-retest correlation was .84

\section{Discussion}

The purpose of this work was to translate, adapt, and analyze the psychometric properties of the RSES in a sample of university students. In general, the results have shown that the scale presents a one-factor structure, with good levels of internal consistency and temporal stability.

Regarding scale structure, CTCU and CTCM models were contrasted. As stated by Tomás, Hontangas, and Oliver (2000) and Horan, DiStefano, and Motl (2003), these models are preferable when there are various trait-method indicators,

Table 5

Correlations between Self-Esteem and Self-Concept Dimensions

\begin{tabular}{lcccccc}
\hline & 1 & 2 & 3 & 4 & 5 & 6 \\
\hline 1. Self-esteem & - & $.38^{* *}$ & $.28^{* *}$ & $.50^{* *}$ & $.28^{* *}$ & $.46^{* *}$ \\
2. Academic self-concept & & - & $.33^{* *}$ & $.12^{*}$ & $.31^{* *}$ & $.45^{* *}$ \\
3. Social self-concept & & - & $.17^{* *}$ & $.13^{* *}$ & $.33^{* *}$ \\
4. Emotional self-concept & & & - & $.13^{* *}$ & $.17^{* *}$ \\
5. Family self-concept & & & & $.16^{* *}$ \\
6. Physical self-concept & & & & - \\
${ }^{*} p<.05 .{ }^{* *} p<.01$. & & &
\end{tabular}


because they present fewer identification and definition problems and they provide unequivocal evidence about the cause of the method effect. However, when CTCM models present problems (i.e., inappropriate solutions), then CTCU models should be used (Lance, Noble, \& Scullen, 2002). In our case, when taking the total sample into account, Model 4 , the one-dimensional model of the scale, has the best indicators, assuming the correlation of the standard errors in the positive items, in accordance with the results of Wang et al. (2001) and in contrast to most of the studies that propose a better fit of factor models with the method effect among the negatively worded items (Corwyn, 2000; Gana et al., 2005; Marsh, 1996; Motl \& DiStefano, 2002).

However, when considering the subsamples as a function of gender, Model 8 (CTCM model with one global self-esteem factor and two correlated method factors that include the positive items on the one hand and the negative ones on the other) presents similar goodness-of-fit indexes to those of Model 4 in the subsample of men. Moreover, when observing men's and women's fit indexes in the other two CTCM models (Models 6 and 7), the women obtain higher goodnessof-fit indexes in Model 6 than in Model 7, whereas this result is reversed in the men. This is relevant because there were more women than men in our study, which could mean that the underlying structure in the total sample would present the method effect among the positive items when, in fact, there could be two structures, one for men and another one for women. In that case, the gender variable would be relevant to produce method effects, like other variables such as age and reading skills, as stated by Marsh (1996) and Corwyn (2000) or the way the items are worded (five positively and five negatively), which would facilitate a response bias independently of their content (Carmines \& Zeller, 1979). In this sense, we could consider that the scale is not factorially invariable in different populations and the method effects may vary from one to another, as indicated by Goldsmith (1986).

However, and in view of the results obtained, we cannot reject the existence of an oblique bidimensionality of the instrument, as found by other authors (Greenberger et al., 2003; Prezza et al., 1997), which would not imply a contradiction with regard to the unidimensionality of selfesteem as a general construct, because the latter would be a higher order dimension. In fact, Greenberger et al. carried out a study in which they compared three versions (the original one, a positive version in which the negatively worded items were worded positively, and a negative version, where the positive items were negatively worded), concluding that, although the two-factor solution of the original scale was better in comparison to the other two versions, they did not observe great differences, and positive correlations were established among the three scales. Thus, general self-esteem could both explain the studies that find a supra- or higher order-dimension that would comprise the items that represent a positive self-image and those that represent a negative selfimage, and the studies that find two correlated dimensions.
With regard to construct validity, the results show a high and significant positive correlation with the five self-concept dimensions. This result is in line with considering self-esteem an evaluative conceptual level of self-concept (Purkey, 1970; Shavelson et al., 1976) and as a worth and evaluative quality of the cognitions and behaviors expressed in the degree of personal satisfaction (Musitu et al., 1988). Likewise, our study corroborates the findings of validation studies carried out in other countries and with different self-concept instruments (Pullmann \& Allik, 2000; Santos \& Maia, 2003).

With reference to the reliability of the scale, it has shown good levels of internal consistency and temporal stability after a 4-week interval, in accordance with previous studies (Rosenberg, 1989; Santos \& Maia, 2003; Vallieres \& Vallerand, 1990).

The results of the gender differences, in general, showed a higher mean score of men in the positive items and a higher mean of women in the negative items. Five of these differences were significant, revealing a higher general selfesteem in men than in women, coinciding with the results obtained in the Portuguese adaptation (Santos \& Maia, 2003) and in contrast to the results found in French samples (Vallieres \& Vallerand, 1990). These differences could be explained by the presence of sociocultural elements.

Future investigations should undertake to study the factor structure of the RSES in the university population taking into account the gender variable to determine whether there are different structures according to gender. On the other hand, it would be interesting to compare a positive version of the instrument with a negative version and the original version in different samples (clinical, educational, and work settings). Likewise, it is necessary to carry out cross-cultural studies with analogous samples using diverse variables such as self-concept, gender, age, or level of studies to establish the construct validity of the instrument and its usefulness to identify differences in self-esteem in different sociocultural contexts.

To sum up, our results confirm the unidimensional structure of the RSES proposed by Rosenberg (1989). Internal consistency and test-retest correlation were good, supporting the reliability of the scale. Furthermore, we consider that there is sufficient evidence to support the construct validity of the scale. Therefore, the results provide justification for the use of the RSES in the university context to assess self-esteem.

\section{References}

Alonso, J., \& Román, J.M. (2005). Prácticas educativas familiares y autoestima. Psicothema, 17, 76-82.

Atienza, F.L., Moreno, Y., \& Balaguer, I. (2000). Análisis de la dimensionalidad de la Escala de Autoestima de Rosenberg en una muestra de adolescentes valencianos. Revista de Psicología Universitas Tarraconensis, 22, 29-42. 
Baños, R.M., \& Guillén, V. (2000). Psychometric characteristics in normal and social phobic simples for a Spanish version of the Rosenberg Self-Esteem Scale. Psychological Reports, 87, 269-274

Bollen, K., \& Long, J.S. (1994). Testing structural equation models. Newbury Park, CA: Sage.

Brislin, R.W. (1986). The wording and translation of research instruments. In W. Lonner \& J. Berry (Eds.), Field methods in cross-cultural research (pp. 137-164). Beverly Hills, CA: Sage.

Carmines, E.G., \& Zeller, R.A. (1979). Reliability and validity assessment. Beverly Hills, CA: Sage.

Corwyn, R.F. (2000). The factor structure of global self-esteem among adolescents and adults. Journal of Research in Personality, 34, 357-379

Cheng, S.T., \& Hamid, P.N. (1995). An error in the use of translated scales: The Rosenberg Self-Esteem Scale for Chinese. Perceptual and Motor Skills, 81, 431-434.

Fiz, M.R., \& Oyón, M.J. (1998). Influencia de la autoestima y su repercusión en el rendimiento académico de los adolescentes. Estudios de Pedagogía y Psicología, 10, 27-74.

Gana, K., Alaphilippe, D., \& Baillo, D. (2005). Factorial structure of the French version of the Rosenberg Self-Esteem Scale among the elderly. International Journal of Testing, 5, 169-176.

Garaigordobil, M., Durá, A., \& Pérez, J.I. (2005). Síntomas psicopatológicos, problemas de conducta y autoconceptoautoestima: un estudio con adolescentes de 14 a 17 años. Anuario de Psicología Clínica y de la Salud, 1, 53-63.

García, F., \& Musitu, G. (2001). AF5, Autoconcepto Forma 5. Madrid: TEA.

Goldsmith, R.E. (1986). Dimensionality of the Rosenberg Self-Esteem Scale. Journal of Social Behavior and Personality, 1, 253-264.

González-Pienda, J., Núñez, J.C., González-Pumariega, S., \& García, M.S. (1997). Autoconcepto, autoestima y aprendizaje escolar. Psicothema, 9, 271-289.

Greenberger, E., Chen, Ch., Dmitrieva, J., \& Farruggia, S.P. (2003). Item-wording and the dimensionality of the Rosenberg SelfEsteem Scale: Do they matter? Personality and Individual Differences, 35, 1241-1254.

Hensley, W.E., \& Roberts, M.K. (1976). Dimensions of Rosenberg's Self-Esteem Scale. Psychological Reports, 38, 583-584.

Horan, P.M., DiStefano, C., \& Motl, R.W. (2003). Wording effects in self-esteem scales: Methodological artifact or response style? Structural Equation Modeling, 10, 435-455.

Hu, L., \& Bentler, P.M. (1999). Cutoff criteria for fit indexes in covariance structure analysis: Conventional criteria versus new alternatives. Structural Equation Modeling, 6, 1-55

Jöreskog, K.G., \& Sörbom, D. (1993). Structural equation modeling with the SIMPLIS command language. Chicago: Scientific Software International.

Kline, R.B. (1998). Principles and practice of structural equation modeling. New York: Guilford Press.

Lance, C.E., Noble, C.L., \& Scullen, S.E. (2002). A critique of the correlated trait-correlated method and correlated uniqueness models for multitrait-multimethod data. Psychological Methods, 7, 228-244.
Marsh, H.W. (1996). Positive and negative self-esteem: A substantively meaningful distinction or artifactors? Journal of Personality and Social Psychology, 70, 810-819.

Mestre, M.V., García, R., Frías, D., \& Llorca, V. (1992). Autoestima, depresión y variables escolares: un estudio longitudinal infanciaadolescencia. Revista de Psicología de la Educación, 4, 5165.

Motl, R.W. \& DiStefano, C. (2002). Longitudinal invariance of self-esteem and methods effects associated with negatively worded items. Structural Equation Modeling, 9, 562-578.

Musitu, G., Román, J.M., \& Gracia, E. (1988). Familia y educación. Barcelona: Labor.

Núñez, J.C., González-Pienda, J.A., García, M., GonzálezPumariega, S., Roces, C., Álvarez, L., \& González, M.C. (1998). Estrategias de aprendizaje, autoconcepto y rendimiento académico. Psicothema, 10, 97-109.

Núñez, J.L., Martín-Albo, J., \& Navarro, J.G. (2005). Validación de la versión española de la Échelle de Motivation en Éducation (EME). Psicothema, 17, 344-349.

Parra, A., Oliva, A., \& Sánchez, I. (2004). Evolución y determinantes de la autoestima durante los años adolescentes. Anuario de Psicología, 35, 331-346.

Pastor, A., Navarro, E., Tomás, J.M., \& Oliver, A. (1997). Efectos de método en escalas de personalidad: la escala de autoestima de Rosenberg. Psicológica, 18, 269-283.

Prezza, M., Trombaccia, F.R., \& Armento, L. (1997). La scala dell'autostima di Rosenberg: traduzione e validazione italiana. Bollettino di Psicologia Applicata, 223, 35-44.

Pullman, H., \& Allik, J. (2000). The Rosenberg Self-Esteem Scale: Its dimensionality, stability and personality correlates in Estonia. Personality and Individual Differences, 28, 701-715.

Purkey, W.W. (1970). Self-concept and school achievement. Englewood Cliffs, NJ: Prentice-Hall.

Quilty, L.C., Oakman, J.M., \& Risko, E. (2006). Correlates of the Rosenberg Self-Esteem Scale method effects. Structural Equation Modeling, 13, 99-117.

Rodríguez, S., Cabanach, R.G., Valle, A., Núñez, J.C., \& GonzálezPienda, J.A. (2004). Diferencias en el uso de self-handicapping y pesimismo defensivo y sus relaciones con las metas de logro, la autoestima y las estrategias de autorregulación. Psicothema, 16, 625-631.

Rosenberg, M. (1965). Society and the adolescent self-image. Princeton, NJ: Princeton University Press.

Rosenberg, M. (1989). Society and the adolescent self-image. (Rev. ed.). Middeltown, CT: Wesleyan University Press.

Salgado, J.F., \& Iglesias, M. (1995). Estructura factorial de la Escala de Autoestima de Rosenberg: un análisis factorial confirmatorio. Psicológica, 16, 441-454.

Sánchez, E., \& Barrón, A. (2003). Social psychology of mental health: The social structure and personality perspective. The Spanish Journal of Psychology, 6, 3-11.

Santos, P.J., \& Maia, J. (2003). Análise factorial confirmatória e validaçao preliminar de uma versao portuguesa da escala de auto-estima de Rosenberg. Psicologia: Teoria, Investigaçao e Prática, 2, 253-268. 
Schmitt, D.P., \& Allik, J. (2005). Simultaneous administration of the Rosenberg Self-Esteem Scale in 53 nations: Exploring the universal and culture-specific features of global selfesteem. Journal of Personality and Social Psychology, 89, 623-642.

Shapurian, R., Hojat, M., \& Nayerahmadi, H. (1987). Psychometric characteristics and dimensionality of a Persian version of the Rosenberg Self-Esteem Scale. Perceptual and Motor Skills, 65, 27-34.

Shavelson, J., Hubner, J.J., \& Stanton, G.C. (1976). Self-concept: Validation of construct interpretations. Review of Educational Research, 46, 407-442.

Tomás, J.M., Hontangas, P.M., \& Oliver, A. (2000). Linear confirmatory factor models to evaluate multitrait-multimethod matrices: The effects of number of indicators and correlation among methods. Multivariate Behavioral Research, 35, 469499.
Tomás, J.M., \& Oliver, A. (1999). Rosenberg's Self-Esteem Scale: Two factors or method effects. Structural Equation Modeling, 6, 84-98.

Vallieres, E.F., \& Vallerand, R.J. (1990). Traduction et validation Canadienne-Française de l'Echelle de l'Estime de soi de Rosenberg. International Journal of Psychology, 25, 305-316. Vázquez, A.J., Jiménez, R., \& Vázquez-Morejón, R. (2004). Escala de autoestima de Rosenberg: fiabilidad y validez en población clínica española. Apuntes de Psicología, 22, 247-255.

Wang, J., Siegal, H.A., Falck, R.S., \& Carlson, R.G. (2001). Factorial structure of Rosenberg's Self-Esteem Scale among crack-cocaine drug users. Structural Equation Modeling, 8, 275-286.

Received May, 18, 2006

Revision received April, 11, 2007

Accepted May, 23, 2007 